13-SYSTEMATIC REVIEW AND META-ANALYSIS

\title{
Oxandrolone use in adult burn patients. Systematic review and meta-analysis
}

\author{
Daniel Sundfeld Spiga Real', Rodrigo Pacheco Reis ${ }^{\mathrm{I}}$, Monica Sarto Piccolo ${ }^{\mathrm{II}}$, Regina H. Okamoto ${ }^{\mathrm{III}}$, Alfredo Gragnani ${ }^{\mathrm{IV}}$, Lydia
} M. Ferreira ${ }^{v}$.

DOI: http://dx.doi.org/10.1590/S0102-86502014001700013

${ }^{I}$ MD. Resident of Plastic Surgery Discipline of Federal University of São Paulo -EPM/UNIFESP, São Paulo, SP, Brazil

${ }^{\text {II }} \mathrm{MD}$, Master. Fellow PhD degree of Post-Graduation Program of Translational Surgery of Federal University of São Paulo -EPM/UNIFESP, São Paulo, SP, Brazil

${ }^{\text {III } M D, ~ P h D . ~ A t t e n d i n g ~ P h y s i c i a n ~ o f ~ P l a s t i c ~ S u r g e r y ~ D i s c i p l i n e ~ o f ~ F e d e r a l ~ U n i v e r s i t y ~ o f ~ S a ̃ o ~ P a u l o-~ E P M / U N I F E S P, ~ S a ̃ o ~ P a u l o, ~ S P, ~ B r a z i l ~}$

${ }^{\text {IV }} \mathrm{MD}$, PhD. Full Professor of Plastic Surgery Discipline of Federal University of São Paulo- EPM/UNIFESP, São Paulo, SP, Brazil

${ }^{\vee}$ MD, PhD, Chairwomam and Full Professor of Plastic Surgery Discipline of Federal University of São Paulo- EPM/UNIFESP, São Paulo, SP, Brazi

\section{ABSTRACT}

PURPOSE: This study is a systematic literature review and meta-analysis concerning the use of a testosterone synthetic analog, oxandrolone, and its use in severe adult burns.

METHODS: Randomized prospective clinical studies, in English, Portuguese or Spanish, were sought on the following databases: MEDLINE, COCHRANE, EMBASE and LILACS. There was no restriction in relation to the publication date.

RESULTS: This search produced 24 studies on MEDLINE and twelve articles were presented on the COCHRANE database .Sixteen were excluded due to the title not being related to this search or by including children. Of the eigth residual studies, after adaptation to the inclusion criteria, only four were selected. After analyzing the results, two were discarded since they did not present adequate patient characterization and the facts on these articles were analyzed differently from the others, hindering the meta-analysis.

CONCLUSION: The analysis of the available data demonstrated significant benefits $(\mathrm{p}<0.05)$ considering lesser loss of corporal mass, lesser nitrogen loss, and shorter donor area healing time, when Oxandrolone was used, comparatively with the control group (placebo or not).

Key words: Oxandrolone; Burns; Adults; Systematic review; Meta-analysis. 


\section{Introduction}

Burn injuries and their sequelae have been present for centuries as major importance world problems. It is referred that over 1.2 million individuals will sustain a burn injury every year in the USA, being that the majority of these lesions are small burns, treated in the ambulatory. However, approximately 60,000 cases are moderate or severe and require hospitalization for their treatment. Furthermore, it is estimated that 5,000 deaths occur every year in the USA due to Burns or their complications ${ }^{1}$.

Corroborating to ratify the importance of the burn patient, and the need for improvements in their care, Bull and Fisher, in 1949, reported a $50 \%$ mortality rate for children (0-14) with $49 \%$ TBSA, for young adults (15-44) with 46\% TBSA, for individuals between 45 and 64 with a $27 \%$ TBSA and for those older than 65 , $10 \% \mathrm{TBSA}^{2}$. These statistics have improved considerably with the advances in critical patients care, with current data showing a $50 \%$ mortality rate in children up to 14 with $98 \%$ TBSA and in young adults with over $75 \% \mathrm{TBSA}^{3,4}$.

Data available through the Brazilian Burn Society indicate that, in Brazil, there are one million burn cases each year; 200 thousand are seen in emergency services and 40 thousand will need hospital admission. Burns area amongst the main external death causes in Brazil, second only to other violent causes, such as traffic accidents and manslaughter ${ }^{5}$. A study on a hospital in Brasilia demonstrated a $6.2 \%$ death rate in burn patients admitted to an emergency hospital ${ }^{6}$.

As shown, it is noted the importance of the optimization of burn patient care in its acute phase, in intensive care, as well as in the recovering and rehabilitation phases, not forgetting that prevention is the best treatment.

Severe Burns will cause a great increment in catabolic rates, leading to lean mass consumption and decrease in protein reserve. Decreasing the lean mass will lead to a deficiency in wound healing and in muscle-skeletal function ${ }^{7-13}$. Testosterone analogs have been reported in the literature as substances which will decrease protein loss and stimulate anabolism ${ }^{14-18}$.

Oxandrolone is a synthetic analog, 17 alpha-methyl, derived from testosterone with frequent use in a large number of critical patients, such as advanced hepatopathies, HIV, cardiac cachexia, major Burns and other hyper catabolic patients, showing restoration in lean mass together with improved nutrition ${ }^{17-20}$.

However, few studies permeate oxandrolone anticatabolic action on major burn patients ${ }^{21-23}$. This action consists in diminishing protein and lean mass loss, shortening wound healing time and donor area reepithelisation, as well as possible hospital stay decrease ${ }^{16,17}$.

Based on the knowledge related to this subject, the objective of this systematic review study is to list the effects of oxandrolone in major adult burn patients, since there are few studies related to this theme on the literature, what rectifies the lack of protocol and systematization for its use in major burns units. As such, this review intends to serve as evidence for the secure and systematic use of Oxandrolone in the acute treatment as well as in the rehabilitation of adult patients with severe burns.

\section{Objectives}

The objective of this study is to respond the question about the use of oxandrolone in adult patients with severe burns, in relation to the time of wound healing of donor site, the nitrogen loss and the body mass loss.

\section{Methods}

To attain this objective, a selection of studies was performed within the main databases and its results were analyzed through a meta-analysis, according to the protocols of COCHRANE ${ }^{25}$.

\section{Selection Criteria}

For selection criteria, the search was performed within the main health databases: MEDLINE, COCHRANE, EMBASE e LILACS, the period of February 2014, using the key words: severe burn and oxandrolone. As filters, language was restricted to Portuguese, English and Spanish.

The first selection was done through reading the titles, excluding all articles which had children in the study. Later, other factor was the study design, being that clinical, randomized and prospective studies were selected.

As results,

- MEDLINE: the search produced 24 articles. Nine were excluded due to the title not being related to this search and seven were excluded because they included studies in children. Of the eight residual studies, two were literature reviews which were also excluded since they did not obey the inclusion criteria and six clinical trials, one was excluded for being retrospective and observational and other was selected to the systematic review. Of these five 
articles, four were included in the systematic review and one excluded after reading the abstract because it was not about the subject of this review.

- COCHRANE: 12 articles were presented: two systematic reviews were excluded for not being related to the search criteria of this research and ten controlled studies, of which five were exclude for being related to children or not corresponding to the theme. Four presented correspondence with those of MEDLINE

- The other bases surveyed did not return any results.

\section{Study Type}

The four selected studies according to the search criteria were:

- Demling R. (1999) ${ }^{21}$ : Prospective, randomized, case controlled study

- Demling R, Orgill PD. (2000) ${ }^{22}$ : Prospective, randomized, double-blind, case controlled study

- Demling R, DeSanti L. (2003) ${ }^{23}$ : Prospective, randomized, case controlled study

- Wolf SE et Col. (2006) $)^{24}$ : Prospective, multicentre, randomized, double blind, case-controlled study

\section{Study subjects}

Subject groups, per study:

- Demling R. (1999) ${ }^{21}$ : Sequential patients who fitted the criteria for the use of anabolic agent, admitted to the burn center in 1996 and 1997. Patients were randomized either to a group using Human Growth Hormone (HGH) or Oxandrolone, The patients with major burns whom did not fit the inclusion criteria for either group were the control group.

The groups were characterized as such:

1. Deep burns, 2 nd or 3rd degree over 50\% TBSA, with at least half of the area needing skin grafting.

2. Deep burns, 2nd and 3rd degree over 25\% TBSA, with comorbidities, such as: older than 60 , malnutrition and adults with diabetes.

- Demling R, Orgill PD. (2000)22: Sequential patients admitted to the burn center during 1998, which fitted the inclusion criteria. Patients were randomized in control and oxandrolone groups. Randomization was in a double blind pattern - caretakers did not know the groups, only the pharmacists. Criteria for inclusion were:
- Patients with deep burns (2nd and 3rd degree) with 40 to $70 \%$ TBSA, including those with inhalation injury and other comorbidities factors and at least 20\% TBSA requiring grafting.

- Demling R, DeSanti L. (2003) ${ }^{23}$ : Patients with large burns whom were transferred to the Brigham and Women's Hospital Burn Center between 1999 and 2001. Patients were randomized in one group receiving physical exercises and optimized nutrition and one group receiving Oxandrolone and physical exercised and optimized nutrition. Patients with prostate or breast cancer history and with elevation of PSA were excluded from the study.

- Wolf SE et al. (2006) ${ }^{24}$ : Multicentric study in 14 Burn Centers. Inclusion criteria: patients of either sex, older than 18 , with TBSA equal or greater to $20 \%$. Patients fed orally or through enteral tube up to $5^{\text {th }}$ day after burn and no associated injury (spinal injury, cerebral hypoxia, etc) Exclusion criteria: primary electrical or chemical injury, pregnancy, chronic liver disease, renal failure, cancer, recent or continuous use of steroids or anabolic agents and participation in other studies

\section{Intervention Types}

- Demling R. (1999) ${ }^{21}$ : Patients randomized in three groups according to criteria in 3.1.2 above, in three groups: Control Group ( $\mathrm{n}=24)$ without the use of anabolic agents; HGH Group ( $\mathrm{n}=20)$, with patients using $\mathrm{HGH}$ at $0.1 \mathrm{mg}$ / $\mathrm{kg}$, intramuscularly, starting 7 to 10 days post-burn; and Oxandrolone Group ( $\mathrm{n}=16)$ using Oxandrolone at $20 \mathrm{mg}$ /day orally, starting 7 to 10 days post burn. All patients received optimized nutrition primarily based on the basal metabolic rate, according to the method of Wilmore et $a .^{24}$. After the first week, required calories were adjusted according to indirect calorimetric and respiratory coefficient. Follow up was up to the transfer to a rehabilitation center, with resolution of the metabolic response to trauma, with clean wounds in less than $15 \%$ of burn surface area.

- Demling R, Orgill PD. (2000) 22 : Patients devided into two randomized groups: Control Group $(n=9)$, with similar characteristics ad the index group, using placebo pills containing $150 \mathrm{mg}$ of lactulose, corn extract and methyl-cellulose - four pills orally, twice a day, starting 2 to 4 days post burn and Oxandrolone Group $(n=11)$, 
four pills, identical as the placebo ones, taken orally twice a day, starting 2 to 4 days post burn. These pills contained 2,5 mg Oxandrolone, $150 \mathrm{mg}$ lactulose, corn extract and methyl cellulose. This regimen totaled 20 mg Oxandrolone per day, which is the dose considered standard in the literature for critically ill patients ${ }^{17,18}$. Double blind study in which patients were accompanied until transferred to a rehabilitation unit. Transfers occurred when there was no longer a metabolic response to trauma; the wound has been cleaned and with less than $10 \%$ total burn surface area (TBSA).

- Demling R, DeSanti L. (2003) ${ }^{23}$ : Patients with severe burns randomized in two groups: Control Group (n-22) with optimized nutrition and exercises; and Oxandrolone Group ( $\mathrm{n}=23$ ) - defined through inclusion criteria, whom received $20 \mathrm{mg}$ Oxandrolone orally per day, in two dosages and optimized nutrition and exercises. Patients were followed regularly up to six months after no longer using Oxandrolone.

- Wolf SE et al. (2006) ${ }^{24}$ : Patients who fitted the inclusion criteria were placed into groups according to age and\% TBSA. In relation to age: $18-44,45-64$ adn over 65 ; in relation to burnt area: $20-30 \%, 31-40 \%, 41-50 \%$ and $51-$ $60 \%$ TBSA. After separating into these criteria, patient were randomized into two groups: Control Group ( $n=35)$ who received a pill containing sacarose and the Oxandrolone group ( $\mathrm{n}=46)$ who received an identical pill in appearance, containing $10 \mathrm{mg}$ of Oxandrolone every 12 hours, orally or via tube, starting on the fifth day post burn extending to hospital discharge. Oral or enteral nutrition, surgical procedures for debridement or grafting were offered to all patients according to each institution criteria. Hepatic enzymes were measured when clinically indicated.

\section{Revision Method}

\section{Clinical Assay Selection}

Clinical assays were selected based in the analyzed data presenting the results of Oxandrolone use. With this aim, two studies were selected which presented enough information for the meta- analysis. Demling R (1999) ${ }^{21}$ and Demling R, Orgill PD $(2000)^{22}$. The third study Demling R, DeSanti L ( 2003) ${ }^{23}$ was excluded for not clearly defining the patient with severe burn, and also analyzing gain of body mass in the acute phase instead of loss. In relation to the fourth study, Wolf SE et al. (2006) ${ }^{24}$, it was not possible to compare its data via meta-analysis, because correspondence with the other studies were only in relation to length of hospital stay, and among the complications, hepatic enzymes analysis.

\section{Data Acquisition and Analysis}

Data analysis was performed through meta-analysis using as comparison factors averages, standard deviations and number of individuals in each group of the selected studies.

For data processing, an electronic tool known as "Comprehensive Meta Analysis"26 was used. It is virtually available for tests, correlation coefficient, odds ratio and Fisher Z relation calculations.

All data were displayed in tables and graphs ("florets plot") for a better results visualization.

\section{Results}

\section{Outcomes submitted to Meta-analysis}

The analysis of the outcomes in this study, aiming at analyzing the effects of Oxandrolone use in major burn patients, identified the following aspects:

- Donor area healing time

- Nitrogen balance

- Body mass loss

- Side-effects: liver toxicity, androgenic effect- hirsutism

- Metabolic rate

- Length of hospital stay

\section{Meta-analysis results}

Data analysis presented in table 1, 2 and 3, and their graphs respectively, demonstrate statistically significant benefits of the use of Oxandrolone, when compared to placebo, in relation to lesser body mass loss, lesser nitrogen loss, and lesser donor area healing time. 
When metabolic rate and length of hospital stay are analyzed, there is no statistical difference. Metabolic rate is a normal response to burn injury and there was no difference on its increase between the two groups. Length of stay comparison was hindered because of the small number of patients and the lack of homogeneity amongst the groups.

Table 1/Figure 1 showed through Odds Ratio Log, that the difference among the analyzed factors had significance difference when they are analyzed separately in each study.
Data on Table 2/Figure 2 showed the outcomes significance, through Correlation $\mathrm{R}$ meta-analysis, rectifying individual results.

Table 3/Figure 3 presented data comparison through Fisher Z Score, which corresponds to the linear relation among data of different studies.

TABLE 1 - Factors analyzed separately for each study, as body weight loss, nitrogen loss, metabolic rate, wound healing time of donor site and length of stay.

\begin{tabular}{|c|c|c|c|c|c|c|c|c|c|c|}
\hline Model & Article & Results & $\begin{array}{l}\text { Odds } \\
\text { Ratio } \\
\text { Logo }\end{array}$ & $\begin{array}{l}\text { Standard } \\
\text { Deviation }\end{array}$ & $\begin{array}{c}\text { Confidence } \\
\text { Interval }\end{array}$ & p value & $\begin{array}{c}n- \\
\text { Oxandrolone }\end{array}$ & $\begin{array}{c}\text { n- } \\
\text { Control }\end{array}$ & $\begin{array}{c}\text { Articler } \\
\text { relative } \\
\text { weight } \\
\text { (fixed) }\end{array}$ & $\begin{array}{c}\text { Article } \\
\text { relative } \\
\text { weight } \\
\text { (random) }\end{array}$ \\
\hline & $\begin{array}{l}\text { Demling } \\
\text { R. (1999) }\end{array}$ & $\begin{array}{c}\text { Body mass } \\
\text { lossl }(\mathrm{Kg})(1)\end{array}$ & 3,421 & 0,699 & $2,051-4,792$ & 0,000 & 16 & 24 & 12,32 & 10,37 \\
\hline & $\begin{array}{l}\text { Demling } \\
\text { R. (1999) }\end{array}$ & $\begin{array}{c}\text { Nitrogen loss } \\
\text { (g/day) (2) }\end{array}$ & 5,451 & 0,845 & $3,795-7,107$ & 0,000 & 16 & 24 & 8,44 & 10,01 \\
\hline & $\begin{array}{l}\text { Demling } \\
\text { R. (1999) }\end{array}$ & $\begin{array}{c}\text { Metabolic } \\
\text { rate }(\%)(3)\end{array}$ & $-0,684$ & 0,590 & $-1,841-0,473$ & 0,247 & 16 & 24 & 17,28 & 10,62 \\
\hline & $\begin{array}{l}\text { Demling } \\
\text { R. (1999) }\end{array}$ & $\begin{array}{c}\text { Donor Area } \\
\text { Healing time } \\
\text { ( days) }(4)\end{array}$ & 3,628 & 0,712 & $2,232-5,023$ & 0,000 & 16 & 24 & 11,88 & 10,34 \\
\hline & $\begin{array}{l}\text { Demling } \\
\text { R. (1999) }\end{array}$ & $\begin{array}{l}\text { Length of } \\
\text { Stay (5) }\end{array}$ & $-0,210$ & 0,586 & $-1,359-0,938$ & 0,719 & 16 & 24 & 17,55 & 10,62 \\
\hline & $\begin{array}{l}\text { Demling } \\
\text { R, Orgill } \\
\text { PD } \\
(2000)\end{array}$ & $\begin{array}{c}\text { Body mass } \\
\text { loss }(\mathrm{Kg})(6)\end{array}$ & 3,684 & 1,033 & $1,659-5,709$ & 0,000 & 11 & 8 & 5,64 & 9,48 \\
\hline & $\begin{array}{l}\text { Demling } \\
\text { R, Orgill } \\
\text { PD } \\
(2000)\end{array}$ & $\begin{array}{l}\text { Nitrogen Loss } \\
\text { (g/day) (7) }\end{array}$ & 5,459 & 1,223 & $3,063-7,855$ & 0,000 & 11 & 8 & 4,03 & 8,92 \\
\hline & $\begin{array}{l}\text { Demling } \\
\text { R, Orgill } \\
\text { PD } \\
(2000)\end{array}$ & $\begin{array}{l}\text { Metabolic } \\
\operatorname{rate}(\%)(8)\end{array}$ & $-0,267$ & 0,844 & $-1,921-1,387$ & 0,752 & 11 & 8 & 8,46 & 10,01 \\
\hline & $\begin{array}{c}\text { Demling } \\
\text { R, Orgill } \\
\text { PD } \\
(2000)\end{array}$ & $\begin{array}{c}\text { Donor Area } \\
\text { Healing Time } \\
\text { (days) }(9)\end{array}$ & 2,948 & 0,969 & $1,048-4,847$ & 0,002 & 11 & 8 & 6,42 & 9,67 \\
\hline & $\begin{array}{l}\text { Demling } \\
\text { R, Orgill } \\
\text { PD } \\
(2000)\end{array}$ & $\begin{array}{l}\text { Length of } \\
\text { Stay (10) }\end{array}$ & $-1,292$ & 0,868 & $-2,994-0,411$ & 0,137 & 11 & 8 & 7,99 & 9,95 \\
\hline Fixed(11) & & & 1,648 & 0,245 & $1,167-2,129$ & 0,000 & & & & \\
\hline $\begin{array}{l}\text { Random } \\
\text { (12) }\end{array}$ & & & 2,147 & 0,800 & $0,579-3,716$ & 0,007 & & & & \\
\hline
\end{tabular}



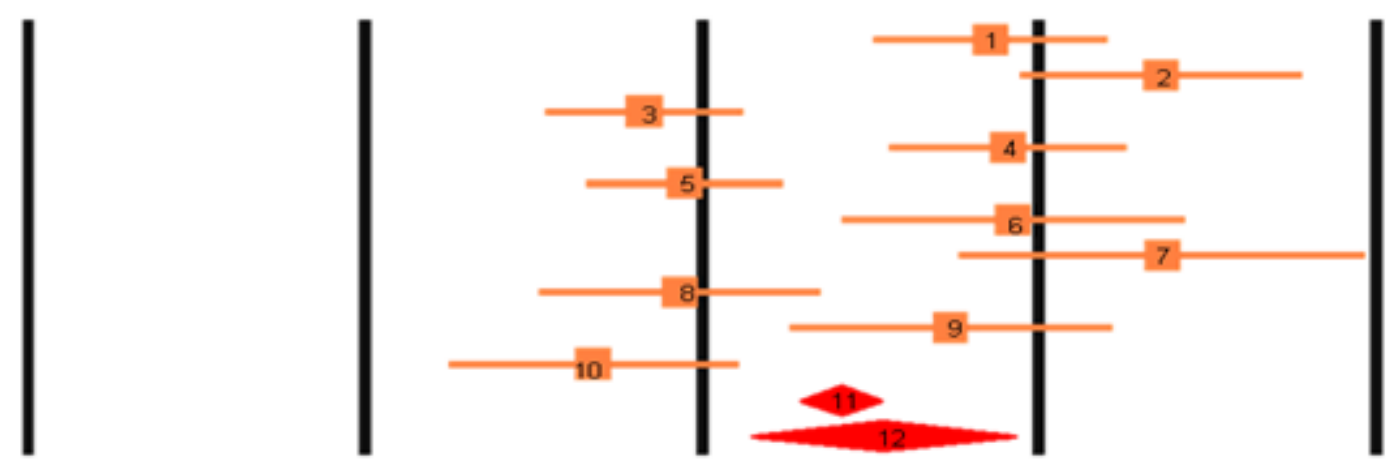

Control

Oxandrolone

FIGURE 1 - Log Odds Ratio meta-analysis. CI - 95\%.

TABLE 2 - Factors analyzed separately in each study for "R" correlation, as body weight loss, nitrogen loss, metabolic rate, cicatrization time of donor site and length of stay.

\begin{tabular}{|c|c|c|c|c|c|c|c|c|c|c|}
\hline Model & Article & Results & Correlation & \begin{tabular}{|c|}
$\mathrm{Z}$ \\
value
\end{tabular} & $\begin{array}{c}\text { Confidence } \\
\text { Interval }\end{array}$ & $\begin{array}{c}\mathbf{p} \\
\text { Value }\end{array}$ & $\begin{array}{c}\text { n- } \\
\text { Oxandrolone }\end{array}$ & $\begin{array}{c}\text { n- } \\
\text { Control }\end{array}$ & $\begin{array}{c}\text { Article } \\
\text { Relative } \\
\text { Weight } \\
\text { (fixed) }\end{array}$ & \begin{tabular}{|c|} 
Article \\
Relative \\
Weight \\
(random) \\
\end{tabular} \\
\hline & $\begin{array}{c}\text { Demling R. } \\
\text { (1999) }\end{array}$ & $\begin{array}{c}\text { Nitrogen } \\
\text { loss(g/day) } \\
(2) \\
\end{array}$ & 0,827 & 9,196 & $0,730-0,892$ & 0,000 & 16 & 24 & 16,72 & 10,47 \\
\hline & $\begin{array}{c}\text { Demling R. } \\
\text { (1999) }\end{array}$ & $\begin{array}{c}\text { Metabolic } \\
\text { Rate (\%) (3) }\end{array}$ & $-0,182$ & $-1,171$ & $-0,455-0,123$ & 0,242 & 16 & 24 & 11,19 & 10,22 \\
\hline & $\begin{array}{c}\text { Demling R. } \\
\text { (1999) }\end{array}$ & $\begin{array}{c}\text { Donor Area } \\
\text { Healing TIme } \\
(\text { days })(4)\end{array}$ & 0,700 & 6,310 & $0,535-0,813$ & 0,000 & 16 & 24 & 14,57 & 10,40 \\
\hline & $\begin{array}{c}\text { Demling R. } \\
\text { (1999) }\end{array}$ & $\begin{array}{l}\text { Length of } \\
\text { stay (5) }\end{array}$ & $-0,057$ & $-0,360$ & $-0,351-0,248$ & 0,719 & 16 & 24 & 11,02 & 10,21 \\
\hline & $\begin{array}{c}\text { Demling R, } \\
\text { Orgill PD } \\
(2000) \\
\end{array}$ & $\begin{array}{c}\text { Nitrogen } \\
\operatorname{loss}(\mathrm{g} / \text { day }) \\
(7) \\
\end{array}$ & 0,830 & 6,389 & $0,677-0,914$ & 0,000 & 11 & 8 & 7,97 & 9,92 \\
\hline & $\begin{array}{c}\text { Demling R, } \\
\text { Orgill PD } \\
(2000)\end{array}$ & $\begin{array}{c}\text { Metabolic } \\
\text { Rate } \\
\text { Metabolic } \\
\text { Rate }(\%)(8)\end{array}$ & $-0,072$ & $-0,317$ & $-0,479-0,360$ & 0,751 & 11 & 8 & 5,24 & 9,43 \\
\hline & $\begin{array}{c}\text { Demling R, } \\
\text { Orgill PD } \\
(2000) \\
\end{array}$ & $\begin{array}{c}\text { Donor Area } \\
\text { Healing Time } \\
(\text { days })(9)\end{array}$ & 0,626 & 3,570 & $0,320-0,814$ & 0,000 & 11 & 8 & 6,5 & 9,70 \\
\hline
\end{tabular}




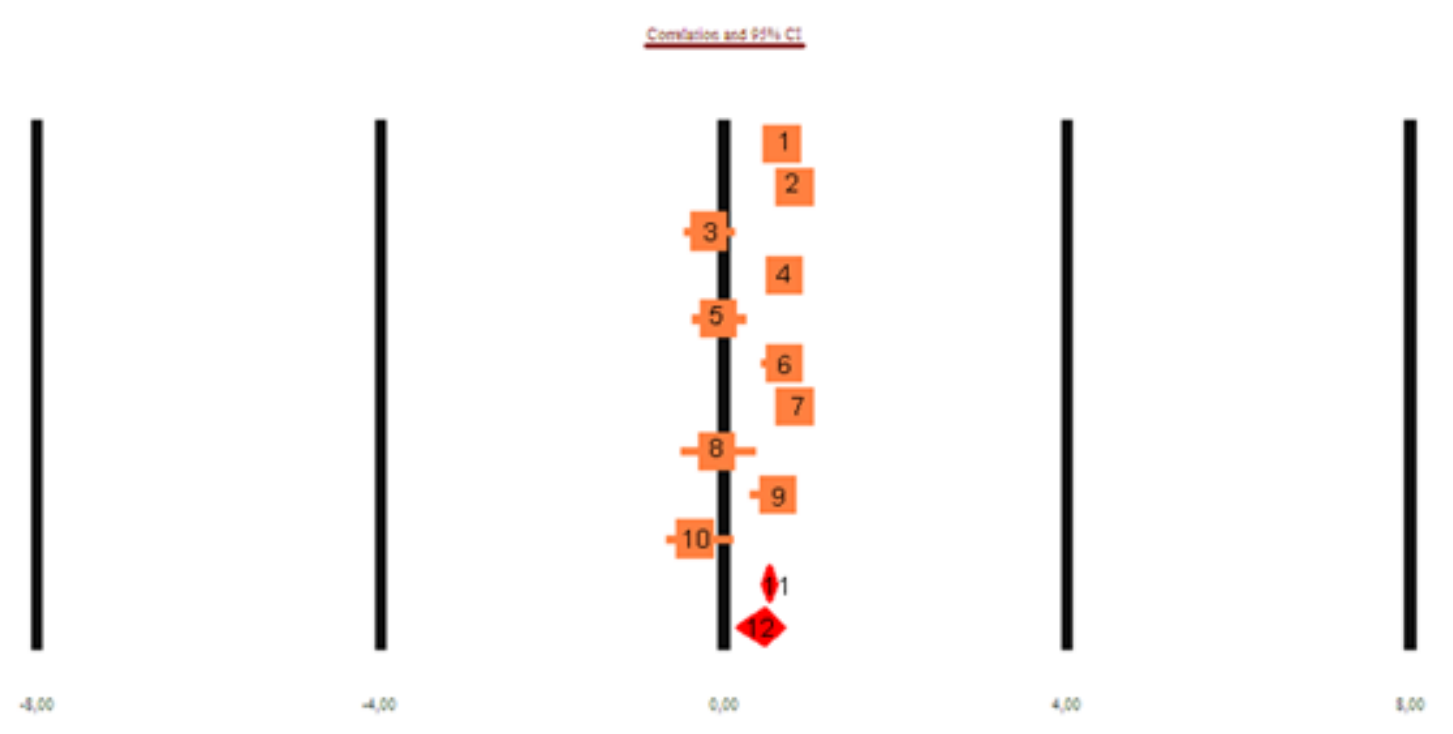

\section{Control}

Oxandrolone

FIGURE 2 - Meta-analysis for correlation (R). CI - 95\%

TABLE 3 - Factors analyzed separately in each study to Fisher's Z, as body weight loss, nitrogen loss, metabolic rate, cicatrization time of donor site and length of stay.

\begin{tabular}{|c|c|c|c|c|c|c|c|c|c|c|}
\hline Model & Article & Resultas & $\begin{array}{c}\text { Fisher's } \\
\text { Z }\end{array}$ & $\begin{array}{l}\text { Standard } \\
\text { Deviation }\end{array}$ & $\begin{array}{c}\text { Confidence } \\
\text { interval }\end{array}$ & \begin{tabular}{c|}
$\mathbf{p}$ \\
value
\end{tabular} & $\begin{array}{c}\text { n- } \\
\text { Oxandrolone }\end{array}$ & \begin{tabular}{|c|} 
n- \\
Control
\end{tabular} & $\begin{array}{l}\text { Article } \\
\text { relative } \\
\text { weight } \\
\text { (fixed) }\end{array}$ & $\begin{array}{c}\text { Article } \\
\text { relative } \\
\text { weight } \\
\text { (random) }\end{array}$ \\
\hline & $\begin{array}{l}\text { Demling } \\
\text { R. (1999) }\end{array}$ & $\begin{array}{c}\text { Body mass loss } \\
(\mathrm{Kg})(1)\end{array}$ & 0,827 & 0,139 & $0,555-1,099$ & 0,000 & 16 & 24 & 14,29 & 10,38 \\
\hline & $\begin{array}{l}\text { Demling } \\
\text { R. (1999) }\end{array}$ & \begin{tabular}{|c|} 
Nitrogen \\
loss(g/day) (2)
\end{tabular} & 1,179 & 0,128 & $0,928-1,431$ & 0,000 & 16 & 24 & 16,72 & 10,47 \\
\hline & $\begin{array}{l}\text { Demling } \\
\text { R. (1999) } \\
\end{array}$ & $\begin{array}{c}\text { Metabolic Rate } \\
(\%)(3)\end{array}$ & $-0,184$ & 0,157 & $-0,491-0,124$ & 0,242 & 16 & 24 & 11,19 & 10,22 \\
\hline & $\begin{array}{l}\text { Demling } \\
\text { R. (1999) }\end{array}$ & $\begin{array}{l}\text { Donor Area } \\
\text { Healing TIme } \\
\text { (days) }(4)\end{array}$ & 0,867 & 0,137 & $0,598-1,136$ & 0,000 & 16 & 24 & 14,57 & 10,40 \\
\hline & $\begin{array}{l}\text { Demling } \\
\text { R. (1999) }\end{array}$ & $\begin{array}{c}\text { Length of stay } \\
(5)\end{array}$ & $-0,057$ & 0,158 & $-0,366-0,253$ & 0,719 & 16 & 24 & 11,02 & 10,21 \\
\hline & $\begin{array}{c}\text { Demling } \\
\text { R, Orgill } \\
\text { PD (2000) } \\
\end{array}$ & $\begin{array}{c}\text { Body mass loss } \\
(\mathrm{Kg})(6)\end{array}$ & 0,883 & 0,199 & $0,494-1,273$ & 0,000 & 11 & 8 & 6,97 & 9,78 \\
\hline & $\begin{array}{c}\text { Demling } \\
\text { R, Orgill } \\
\text { PD (2000) }\end{array}$ & $\begin{array}{c}\text { Nitrogen } \\
\text { loss }(g / \text { day })(7)\end{array}$ & 1,187 & 0,186 & $0,823-1,551$ & 0,000 & 11 & 8 & 7,97 & 9,92 \\
\hline & $\begin{array}{c}\text { Demling } \\
\text { R, Orgill } \\
\text { PD (2000) }\end{array}$ & $\begin{array}{c}\text { Metabolic Rate } \\
\text { Metabolic Rate } \\
(\%)(8)\end{array}$ & $-0,073$ & 0,229 & $-0,522-0,376$ & 0,751 & 11 & 8 & 5,24 & 9,43 \\
\hline & $\begin{array}{c}\text { Demling } \\
\text { R, Orgill } \\
\text { PD (2000) }\end{array}$ & $\begin{array}{l}\text { Donor Area } \\
\text { Healing Time } \\
\text { (days) }(9)\end{array}$ & 0,734 & 0,206 & $0,331-1,138$ & 0,000 & 11 & 8 & 6,50 & 9,70 \\
\hline & $\begin{array}{c}\text { Demling } \\
\text { R, Orgill } \\
\text { PD (2000) }\end{array}$ & $\begin{array}{c}\text { Length of Stay } \\
(10)\end{array}$ & $-0,345$ & 0,223 & $-0,782-0,092$ & 0,122 & 11 & 8 & 5,53 & 9,50 \\
\hline Fixed (11) & & & 0,596 & 0,052 & $0,493-0,699$ & 0,000 & & & & \\
\hline Random (12) & & & 0,511 & 0,184 & $0,149-0,872$ & 0,006 & & & & \\
\hline
\end{tabular}




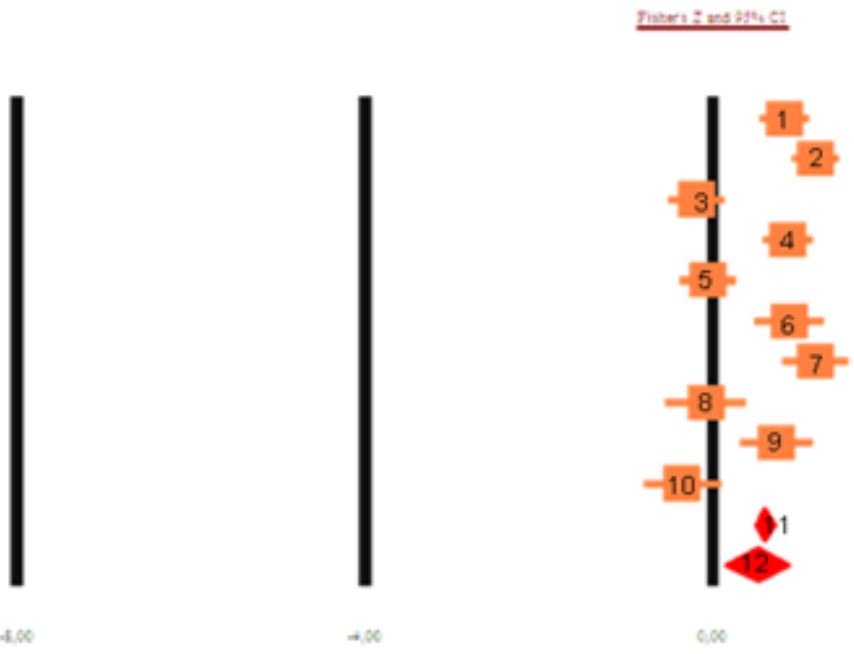

\section{Control}

FIGURE 3 - Fisher's Z Score meta-analysis. CI - 95\%

\section{Discussion}

Major burn patients (over 20\%TBSA) represent a great challenge in their care and a great importance to society, when considering the seriousness of their acute phase and the lengthy sequelae treatment period, as well as the treatment cost and difficult physical and social rehabilitation ${ }^{1,2}$.

As gathered from the literature, it becomes clear that as the percentage of body mass loss increases, so do the complications. A $10 \%$ body mass loss will lead to immune dysfunction; $20 \%$ to impaired wound healing; 30\%, severe infections and 40\%, death ${ }^{27}$. As the catabolism increases, it will also lead to a proportional increase in nitrogen loss.

It is well accepted that a shorter donor area healing time is imperative, since there are few donor areas in major burn patients. Obviously, the faster healing occurs, the faster skin can be re-harvested, and consequently more wounded areas covered.

Major burns will lead to an increase in catabolic rates, leading to lean mass use and decreased protein storage. Lean mass loss will lead to healing and muscle-skeletal impairment ${ }^{7-13}$. Testosterone analogs have been reported as substances which will lead to a lesser protein loss and to anabolism ${ }^{14-18}$.

Results in this study show that the use of Oxandrolone when compared to control (placebo or not) will lead to significant benefits, such as lesser body mass loss, lesser nitrogen loss and lesser donor area healing time.

The question mote for this meta-analysis has been answered in relation to the effects of Oxandrolone on the recovering of major burn patients. The benefits shown in each study and their results meta-analysis may serve as evidence for the introduction of this treatment in more burn centers which currently are not using it, possibly considering risks, which are not present in this study, in relation to this anabolic agent use.

\section{Conclusion}

\section{Clinical Practice Implications}

As this study has shown a lesser body mass loss, lesser nitrogen loss and lesser donor area healing time with this anabolic agent, we can suggest the adoption of Oxandrolone use for patients whom present with body mass loss, increase in nitrogen loss or hindered donor area or superficial burn wound healing.

Oxandrolone use in burn centers should be more frequent, in an attempt to create a better critically ill patient management protocol. This could lead to a shorter recovering and rehabilitation time, yielding benefits for the patient and minimize expense on the public health system.

\section{Study Limitations}

It must be pointed out that there are only a small number of studies about the use of Oxandrolone in adults. There is a need for new randomized, double blind studies, with a larger number of patients so one could obtain quality evidence. The design should aim at demonstrating a possible shorter hospital stay, a smaller 
incidence of complications, such as infection and the consequent use of antibiotics, as well as other factors like a shorter duration of orotracheal intubation.

For this small number of studies, this study showed a meta-analysis of only two articles, even those of a center and conducted by the same investigator, which could adversely affect the results. However, the observance of the articles included in the systematic review, this can damage becomes relative, as all works reveal better patient outcomes with the use of oxandrolone, especially with regard to length of hospital stay endorsed at work multicenter Wolf SE et al. (2006) ${ }^{24}$.

A faster and better rehabilitation of the major burn patient and the optimization of his or her quality of life would be the main goal of these studies.

\section{References}

1. Brigham PA, McLoughlin E. Burn incidence and medical care in the United States: Estimates, trends, and data sources. J Burn Care Rehabil. 1996;17:95-107.

2. Bull JP, Fisher AJ. A study in mortality in a burn unit: Standards for the evaluation for alternative methods of treatment. Ann Surg. 1949;130:160-73.

3. Herndon DN, Gore DC, Cole M, Desai MH, Linares H, Abston S, Rutan TC, VanOsten T, Barrow RE. Determinants of mortality in pediatric patients with greater than $70 \%$ full thickness total body surface area treated by early excision and grafting. J Trauma. 1987;27:208-12.

4. McDonald WS, Sharp CW, Deitch EA. Immediate enteral feeding is safe and effective. Ann Surg. 1991;213:177-83.

5. Brazil and mortality from external causes in 2000 Available at: http:// www.cip.saude.sp.gov.br/Brasil2000.htm Accessed: December 29, 2004.

6. Macedo JLS, Rosa SC. Estudo epidemiológico dos pacientes internados na Unidade de Queimados: Hospital Regional da Asa Norte, Brasília, 1992-1997. Brasilia Med. 2000; 37:87-92.

7. Newsome T, Mason A, Pruitt B. Weight loss following thermal injury. Ann Surg. 1973;178:215-20.

8. Bessey P, Jiang Z, Johnson D et al. Post traumatic skeletal muscle proteolysis: the role of the hormonal environment. World J Surg. 1989;13:465-70.

9. Jahoor F, Desai M, Herndon D. Dynamics of the protein metabolism response to burn injury. Metabolism. 1988;37:330-6.

10. Wilmore D, Aulick L. Metabolic changes in burned patients. Surg Clin North Am. 1978;58:1173-280.

11. Aulick LH, Wilmore DW. Increased peripheral amino acid release following burn injury. Surgery. 1979;85:560-5.

12. Wilmore D. Catabolic illness. N Engl J Med. 1991;325:695-700.

13. Windsor J. Weight loss with physiologic impairment, a basic indicator of surgical risk. Am Surg. 1992;207:290-5.

14. Fleming R, Johoor F. Effect of recombinant HGH on catabolic hormones following thermal injury. J Trauma. 1992;33:698-703.

15. Mendelhall C, Anderson S, Garcia Pont P et al. A study of oral nutrition support with oxandrolone in malnourished patient with alcoholic hepatitis. Hepatology. 1993;17:564-70.
16. Michelsen C, Askanazi J, Kinney J, Gumps F. Effect of an anabolic steroid on nitrogen balance and amino acid patterns after total hip replacement. J Trauma. 1982;22:410-3.

17. Pitkow H, Labbad Z, Bitgar M. The efects of an anabolic hormone on surgically induced wound healing in lower extremity skeletal muscle in diabetic and normal rats. Wound Rep Reg. 1993;1:119-24.

18.Demling R, DeSanti L. Oxandrolone, an anabolic steroid significantly increases the rate of weight gain in the recovery phase after major burns. J Trauma. 1997;43:47-52.

19. Michelsen C, Askanazi J, Kinney J, et al. Effect of an anabolic steroid on nitrogen balance and amino acid patterns after total hip replacement. J Trauma. 1982;22:410-3.

20. Berger J, Pall L, Simpson D, et al. Oxandrolone in AIDS - wasting myopathy. AIDS. 1996;10:1657-62.

21. Demling R. Comparison of the anabolic effects and complications of human growth hormone and the testosterone analog, oxandrolone, after severe burn injury. Burns. 1999;25:215-21.

22. Demling R, Orgill PD. The anticatabolic and wound healing effects of the testosterone analog oxandrolone after severe burn injury. J Critical Care. 2000;15(1):12-7.

23. Demling R, DeSanti. Oxandrolone induced lean mass gain during recovery from severe burn is maintained after discontinuation of the anabolic steroid. Burns. 2003;29:793-7.

24. Wolf SE, Edelman LS, Kemalyan N, Donison L, Cross J, Underwood M, Spence RJ, Noppenberger D, Palmieri TL, Greenhalgh DG, Lawless M, Voigt D, Edwards P, Warner P, Kagan R, Hatfield S, Jeng J, Crean D, Hunt J, Purdue G, Burris A, Cairns B, Kessler M, Klein RL, Baker R, Yowler C, Tutulo W, Foster K, Caruso D, Hildebrand B, Benjamin W, Villarreal C, Sanford AP, Saffle J. Effects of oxandrolone on outcome measures in the severely burned: a multicenter prospective randomized double-blind trial. J Burn Care Res. 2006 Mar-Apr;27(2):131-9; discussion 140-1.

25. http://handbook.cochrane.org/

26. http://www.meta-analysis.com

27. Williams FN, Jeschke MG, Chinkes DL, et al. Modulation of the hypermetabolic response to trauma: temperature, nutrition, and drugs. J Am Coll Surg. 2009;208:489-502.

\section{Correspondence}

Alfredo Gragnani, MD, PhD (EPM/UNIFESP)

Rua Napoleão de Barros, 715 - 4 andar -

04024002 - São Paulo/SP/Brasil

Tel: 551155764118 Fax: 551155716579

alfredogf@ig.com.br 